Research Article

\title{
Bioaccumulation of mercury in fishes of Jagadishpur Reservoir, Nepal
}

\author{
Prakash Acharya ${ }^{1}$, Chhatra Mani Sharma ${ }^{2,3^{*}}$, Shichang Kang ${ }^{3,4}$, Lekhendra Tripathee ${ }^{3,5}$, \\ Junming Guo ${ }^{3}$, Rukumesh Paudyal ${ }^{3,5}$, Qianggong Zhang ${ }^{4,6}$, Hemraj Bhattarai ${ }^{5,7}$, Mika \\ Sillanpää $8,9,10$
}

${ }^{1}$ Faculty of Applied Ecology and Agricultural Sciences, Hedmark University of Applied Sciences, Hedmark, Norway.

${ }^{2}$ Central Department of Environmental Science, Tribhuvan University, Kathmandu, Nepal.

${ }^{3}$ State Key Laboratory of Cryospheric Sciences, Northwest Institute of Eco-Environment and Resources, Chinese Academy of Sciences, Lanzhou 730000,

China.

${ }^{4}$ CAS Center for Excellence in Tibetan Plateau Earth Sciences, Chinese Academy of Sciences, Beijing 100101, China.

${ }^{5}$ Himalayan Environment Research Institute (HERI), Kathmandu, Nepal.

${ }^{6}$ Key Laboratory of Tibetan Environment Changes and Land Surface Processes, Institute of Tibetan Plateau Research, Chinese Academy of Sciences, Beijing 100101, China.

${ }^{7}$ Earth System Science Programme and Graduate Division of Earth and Atmospheric Sciences, The Chinese University of Hong Kong, Hong Kong, China. ${ }^{8}$ Institute of Research and Development, Duy Tan University, Da Nang 550000, Vietnam.

${ }^{9}$ Faculty of Environment and Chemical Engineering, Duy Tan University, Da Nang 550000, Vietnam.

${ }^{10}$ School of Civil Engineering and Surveying, Faculty of Health, Engineering and Sciences, University of Southern Queensland, West Street, Toowoomba, 4350 QLD, Australia.

\begin{abstract}
Stable isotope ratios of nitrogen $\left(\delta^{15} \mathrm{~N}, \%\right)$ and carbon $\left(\delta^{13} \mathrm{C}, \% 0\right)$, accompanied by stomach contents were used to assess the food chain and trophic transfer of mercury in fifty-three marketable sized fish belonging to five species (Channa punctatus, Mystus vittatus, Nandus nandus, Puntius sophore and Xenentodon cancila) from the Jagadishpur Reservoir, Nepal. The highest total $\mathrm{Hg}$ concentration was found in $X$. cancila with an average of $800.42( \pm 279.36) \mu \mathrm{g} / \mathrm{kg}$ exceeding the international marketing limit $(500 \mathrm{mg} / \mathrm{kg})$, a carnivorous species. However, except for some individuals of $N$. nandus, total $\mathrm{Hg}$ concentrations in other fish species in the present study were significantly lower than that limit. The fish community had at least two trophic levels $\left(\Delta^{15} N>5.6\right)$, C. punctatus with the highest and $M$. vittatus the lowest signatures of $\delta^{15} \mathrm{~N}$, which was also supported by the stomach content analysis. There was neither correlation between total $\mathrm{Hg}$ and $\delta^{15} \mathrm{~N}$ nor connectivity in food resource utilization (based on $\delta^{13} \mathrm{C}$ ), indicating no biomagnification among these fish species. In addition, $\mathrm{Hg}$ concentrations were not significantly correlated to total fish length in any of the species. Fish species in the present study have low $\mathrm{Hg}$ content accompanied by low biomagnification through the studied fish community.
\end{abstract}

Keywords: Fish diet, Stable isotopes of carbon, Stable isotopes of nitrogen, Total mercury, Trophic position

\section{Introduction}

Mercury is pervasive and causes toxic threats to society, mainly through the consumption of aquatic food (e.g., fish). Its concentrations have increased in nature, primarily through human activities (Swain et al., 2007). Methylmercury $(\mathrm{MeHg})$ is the main form of $\mathrm{Hg}$ that has neurotoxic effects on humans and is easily bioaccumulated through the food web (Freije \& Awadh, 2009; Watras et al., 1998), and top predator fish have maximum values in freshwaters (Lockhart et al., 2005). Therefore, in many fish species, total $\mathrm{Hg}$ concentrations are positively correlated to body size and age of fish (Donald et al., 2015; Taylor et al., 2014). Although global $\mathrm{Hg}$ biomagnification remains unexplained entirely (Lavoie et al., 2013), many other factors are controlling the $\mathrm{Hg}$ dynamics in freshwaters bodies; for example, reduced $\mathrm{pH}$ enhances $\mathrm{Hg}$ uptake by fish (Watras et al., 1998), dissolved organic carbon has a positive relationship with $\mathrm{Hg}$ in fish (Belger \& Forsberg, 2006; Lavoie et al., 2013; Watras et al., 1998), size of the lake has negative relations to $\mathrm{Hg}$ in fish (Bodaly et al., 1993), extensive logging activities in the watershed increase
$\mathrm{Hg}$ concentrations in aquatic biota (Garcia \& Carignan, 2000), increment in total phosphorus decreases $\mathrm{Hg}$ magnification (Lavoie et al., 2013).

Stable isotope analysis is used to examine the trophic transfer of $\mathrm{Hg}$ through the food webs of freshwater ecosystems (Lavoie et al., 2013). Nitrogen isotope ratios $\left(\delta^{15} \mathrm{~N}={ }^{15} \mathrm{~N} /{ }^{14} \mathrm{~N}\right)$ are adequate to determine the trophic position of an organism within the food web in an ecosystem (Post, 2002), whereas carbon isotope ratios $\left(\delta^{13} \mathrm{C}\right.$ $={ }^{13} \mathrm{C} /{ }^{12} \mathrm{C}$ ) are useful to find out the origin of different food sources (Campbell et al., 2006). However, the reservoir fisheries with human inputs (e.g., feed) may show abnormally deviated $\delta^{15} \mathrm{~N}$ enrichment than natural water bodies (Wang et al., 2019); thus, trophic levels should cautiously be interpreted.

In Nepal, some studies related to $\mathrm{Hg}$ accumulation in fish fillets in lakes (Sharma et al., 2013; Thapa et al., 2014) and rivers (Pandey et al., 2017) had been conducted. These stud- 
ies focused mainly on $\mathrm{Hg}$ concentrations in fish fillets, and their potential health implications through fish consumption. However, similar studies are lacking from the lowlands of Nepal, particularly from reservoirs. Therefore, the study was carried out to provide baseline data for $\mathrm{Hg}$ contamination in fish from Nepal's lowland region using five major fish species, supposedly representing different trophic levels.

\section{Materials and Methods}

\section{Study area and sampling}

The Jagadishpur Reservoir, a Ramsar Site, is considered a popular tourism hub in Nepal. It is situated at a latitude of $\mathrm{N} 27^{\circ} 37.174^{\prime}$ and a longitude of $\mathrm{E} 083^{\circ} 05.833^{\prime}$ at an elevation of 197 m. above sea level (Fig. 1) with a surface area of 225 ha.

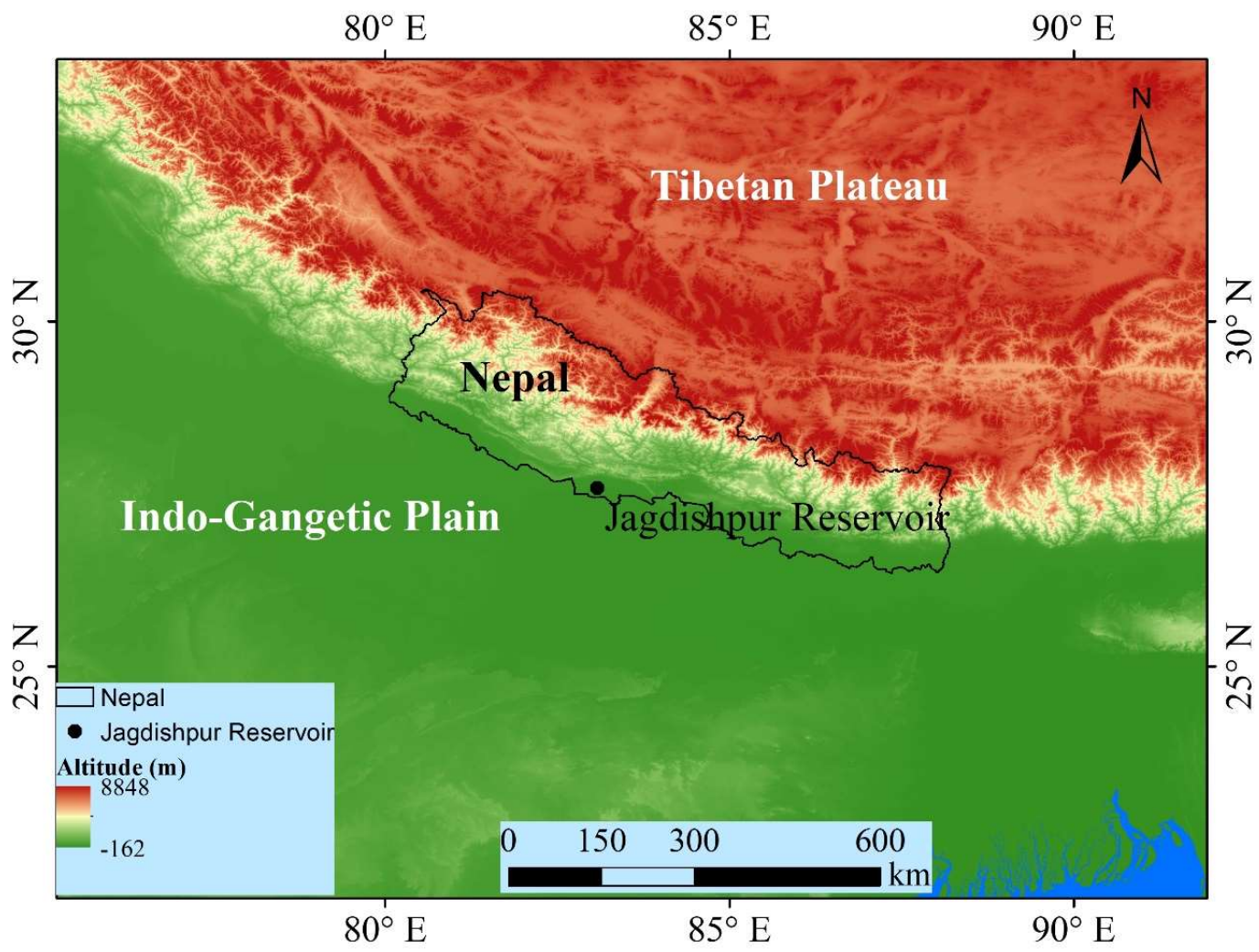

Figure 1 Jagadishpur Reservoir in Nepal lies between the Gangetic Plain in the south and the High Himalayas and the Tibetan Plateau in the north.

The reservoir is eutrophic most of the year and becomes hypereutrophic when phosphorus concentration increases during the monsoon period (Gautam \& Bhattarai, 2008).

Forty-three fish species were recorded by IUCN (2015), of which the five primary fish species Garal (Channa punctatus), Tengerkanti (Mystus vittatus), Dhoke (Nandus nandus), Sidre (Puntius sophore), and Kauwa (Xenentodon cancila) were studied at present. Fifty-three fish were collected during April 2012 using locally available fishing gears (by local fishers) and identified on-site before they were transported to the laboratory and stored in a frozen condition for further analyses. The total length was measured in centimeters $(\mathrm{cm})$ before dissection. Fish muscle sampling was performed following the methods described in Sharma et al. (2008, 2009). Briefly, the axial muscle was collected from each fish after skin removal from the dorsolateral side, between the dorsal fin and lateral line. The muscle samples were kept in the freezer until further analyses in the laboratories.

\section{Analytical procedures}

The muscle was used to analyze total mercury $(\mathrm{THg}), \delta^{15} \mathrm{~N}$, and $\delta^{13} \mathrm{C}$ following the method described by Sharma et al. (2013). Trophic positions of the fish species were determined based on $\delta^{15} \mathrm{~N}$ and $\delta^{13} \mathrm{C}$ values, as Post (2002) and Campbell et al. (2006) explained. The $\delta^{15} \mathrm{~N}$ indicates the relative trophic positions of the organisms whereas $\delta^{13} \mathrm{C}$ gives information on the carbon source of the diet (Sharma et al., 2008).

The methods for $\mathrm{Hg}$ analysis can be found in Pandey et al. (2017) as the muscle samples from this study were analyzed 
together in the same batch. In brief, $\mathrm{THg}$ were analyzed by cold vapor atomic spectrometry using a direct mercury analyzer (Hydra II, Teledyne Leeman Labs, Hudson, NH, USA) after calcination in an $\mathrm{O}_{2}$ stream and amalgamation on an Au trap. The detection limits for the analyses were $0.01 \mathrm{mg} / \mathrm{kg}$ ( 3 times of SD for ten measurements of blanks). The standard materials used for the analytical accuracy and precision measurements were GSS-9 $(n=4)$ and Tort- 2 $(n=3)$. Precisions were within $5.7 \%$ and $1.7 \%$, and the recovery was within $91-107 \%$ and $104-107 \%$ for GSS-9 and Tort-2, respectively. Each sample was measured twice, and if the relative standard deviation (RSD) were $>10 \%$, the sample was measured again. The RSD for all samples was $<$ $6 \%$.

The analytical procedures for the stable isotopes of nitrogen and carbon were followed after Pandey et al. (2017). In brief, an aliquot of each sample was freeze-dried and was then homogenized using a ceramic grinder. The sample was measured for stable isotopes of carbon and nitrogen $\left(\delta^{13} \mathrm{C}\right.$ and $\delta^{15} \mathrm{~N}$ ) with an isotope ratio mass spectrometer (Finnigan MAT Delta V Advantage, Thermo Fisher Scientific, Waltham, MA, USA). Isotopic data are presented in units of per mil (\%o). Stable isotopes $\left(\delta^{13} \mathrm{C}\right.$ and $\left.\delta^{15} \mathrm{~N}\right)$ were determined as

$\delta_{\text {Sample }}(\% 0)=\left[\left(R_{\text {sample }} / R_{\text {standard }}\right)-1\right] \times 1000$

where $R$ is the ratio of heavy to light isotope $\left({ }^{15} \mathrm{~N} /{ }^{14} \mathrm{~N}\right.$ or ${ }^{13} \mathrm{C} /{ }^{12} \mathrm{C}$ ) in the sample, standards are atmospheric air for $\mathrm{N}$ and Pee Dee Belemnite for C. The overall analytical precision was $\pm 0.2 \%$, including sample preparation and analysis.

Stomach contents were preserved in $70 \%$ alcohol and analyzed later under a dissecting microscope. Mean volume percentages of prey in the stomach contents were measured in all fish species, categorized into six items: worms, detritus, aquatic plants, fish insects, and unidentified following Pandey et al. (2017). 14 out of 53 analyzed fish had empty stomachs.

\section{Statistical analysis}

The comparison of $\mathrm{THg}$ in fish muscle was performed by a One-Sample t-test. Correlation and regression analyses were carried out to test relationships among $\mathrm{THg}$ concentrations, $\delta^{15} \mathrm{~N}, \delta^{13} \mathrm{C}$, and total length. The relationship between $\mathrm{THg}$ concentrations and exposure time was explained by the regression of log-THg against the total length of fish. The biomagnification rate of $\mathrm{Hg}$ among the fish community was determined with the regression of $\log$-THg against $\delta^{15} \mathrm{~N}$. Trophic positions of the fish species in the food chain were identified with a simple food web structure based on the relationship between nitrogen isotope $\left(\delta^{15} \mathrm{~N}\right)$ and carbon isotope $\left(\delta^{13} \mathrm{C}\right)$ of the fish species. All the relationships were considered statistically significant at $p \leq 0.05$.

\section{Results and Discussion}

The simple food web structure based on $\delta^{15} \mathrm{~N}$ and $\delta^{13} \mathrm{C}$ showed that $C$. punctatus occupied the highest trophic position, and $M$. vittatus the lowest (Fig. 2). However, our study lacks baseline isotopic data of the prey species; therefore, the figure gives an idea of the relative trophic positions of fish only. Nevertheless, this indicates a food chain of at least two trophic levels $\left(\Delta^{15} \mathrm{~N}>5.6\right)$ in the fish community of Jagadishpur Reservoir, since $\delta^{15} \mathrm{~N}$ increases approximately by three \%o for each trophic level (Vander Zanden \& Rasmussen, 2001). All the individuals from the lowest trophic position (as indicated by the stomach contents and the $\delta^{15} \mathrm{~N}$ signatures), $M$. vittatus had aquatic plants as their dominant diet. The stomach contents of $C$. punctatus, the species at the higher trophic position based on $\delta^{15} \mathrm{~N}$ signatures, were dominated by animal foods (e.g., fish and insects; Fig. 3). Similar results were reported previously from the commercial fish species in Lake Phewa, Pokhara, Nepal (Sharma et al., 2013).

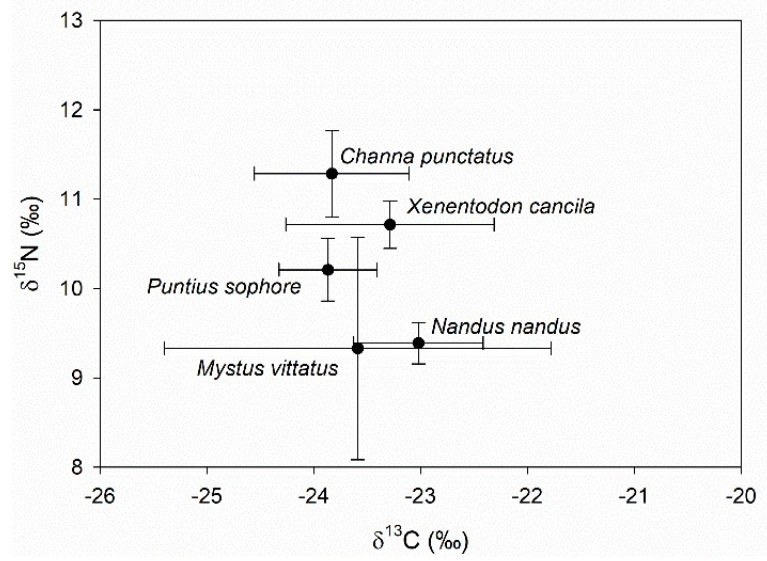

Figure 2 Simple food web structure based on the relationships between $\delta^{15} \mathrm{~N}$ and $\delta^{13} \mathrm{C}$ in five fish species from Jagadishpur Reservoir. Ranges of error bars indicate $95 \%$ confidence interval from the mean: vertical bars for $\delta^{15} \mathrm{~N}$ and horizontal bars for $\delta^{13} \mathrm{C}$ values.

THg concentrations in fish samples were within the range of 65.13 to $1263.54 \mathrm{mg} / \mathrm{kg}$ (w/w) in the present study (Table 1). Channa punctatus had the lowest concentration, whereas carnivorous species $X$. cancila had the highest concentrations of $\mathrm{THg}$. The higher $\mathrm{THg}$ concentrations in $\mathrm{X}$. cancila is probably a result of bioaccumulation of mercury through diet as its food was dominated by fish, worms, and insects (Fig. 3) which was similar to the findings observed by Deribe et al. (2014) on predator fishes in Ethiopian Rift Valley Lakes.

Nandus nandus had the second-highest THg concentrations possibly due to fish as one of the main components in its diet, which was also reported as having mid-range $\mathrm{THg}$ concentration $(90 \mathrm{mg} / \mathrm{kg}$ ) among other fish species in the polluted rivers in Bangladesh (Shoeb et al., 2017). In the remaining species, $\mathrm{THg}$ concentrations were relatively low, which might be because of the consumption of food from lower trophic levels as also mentioned by Campbell et al. (2003) and Desta et al. (2007) for some fishes in Lake Victoria and Lake Awassa, respectively. 


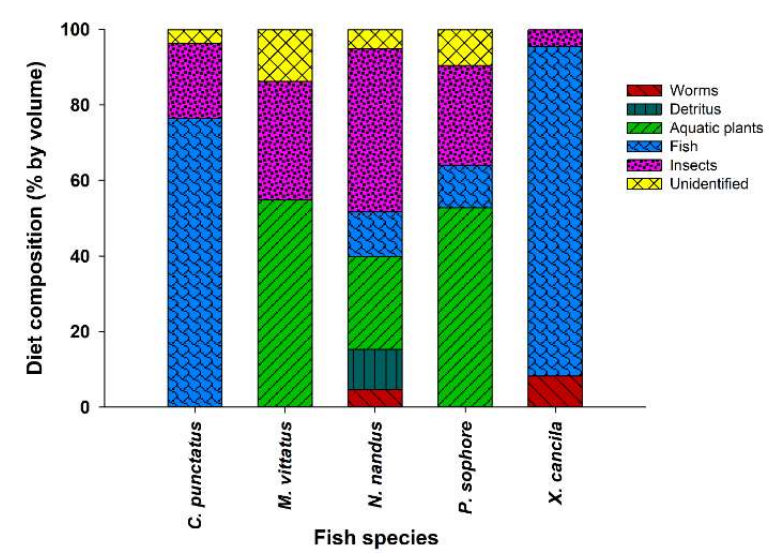

Figure 3 Mean volume (\%) of diet composition (stomach contents) of C. punctatus, M. vittatus, N. nandus, P. sophore, and $X$. cancila.

However, the lowest value of $\mathrm{Hg}$ in C. punctatus in the present study despite having some animal diet in the stomachs (Fig. 3) and highest $\delta^{15} \mathrm{~N}$ values (indicating higher trophic position, Fig. 2) does not follow the general patterns of explanation and needs further investigation. Sometimes, fish species from different trophic levels may have similar mercury concentrations due to unknown reasons. Furthermore, low $\mathrm{Hg}$ concentrations in predator fishes of reservoirs could be due to the short food webs and limited magnification factor compared to natural water bodies $\mathrm{Xu}$ et al., 2018). Although overall average concentrations of total $\mathrm{Hg}$ in fishes from the present study had significantly lower values $(t=-3.87, p<0.001)$ compared to the international marketing limit (500 mg/kg; WHO, 2008), $X$. cancila had significantly exceeded this limit $(t=2.85, p=$ $0.015 ; 86 \%$ individuals exceeded). Furthermore, $45 \%$ of individuals exceeded the marketing limits, although no statistically higher $\mathrm{Hg}$ concentrations were observed in $N$. nandus. Compared to the present study, lower $\mathrm{Hg}$ in fishes was reported by Wang et al. (2019) in an artificial Changshou Lake and Xu et al. (2018) in Three Gorges Reservoirs in China.

In the present study, mercury concentration was not significantly correlated to total fish length in any species (Table 2). This could be due to the disproportionation between fish growth with $\mathrm{Hg}$ bioaccumulation in eutrophic water bodies, as explained by Wang et al. (2019). Furthermore, a possible shift in the diet of old individuals could be a cause for the weak relationship as discovered in a fish species in the Nepalese rivers (Pandey et al., 2017) and some African lakes (Tadiso et al., 2011). This phenomenon is also explained by Desta et al. (2006) as changing the habit of diet by age, where fishes consume zooplankton in the younger stage and aquatic plants when mature. Water management practices, particularly in reservoirs, profoundly influence $\mathrm{Hg}$ bioaccumulation to a great extent (Willacker et al., 2016). Moreover, watershed characteristics and in-lake processes (e.g., food web structure) are also considered important phenomena for controlling $\mathrm{Hg}$ concentrations in a fish community. However, these explanations need further study in the fish community from this reservoir. Although a significant positive relationship was found between log-THg and $\delta^{15} \mathrm{~N}$ for $N$. nandus ( $p=0.038, R=0.47$ ) and $X$. cancila $(p=0.041, R=0.78)$, no significant relationship was found in separate fish species (Table 2) as well as pooled data (Fig. 4).

Table 1 Mean ( \pm SD) and range of length $(\mathrm{cm})$, THg concentrations $\left(\mathrm{mg} / \mathrm{kg}\right.$, ww), $\delta^{13} \mathrm{C}(\%)$ and $\delta^{15} \mathrm{~N}(\%)$ of five different fish species sampled from Jagadishpur Reservoir, Nepal.

\begin{tabular}{|c|c|c|c|c|c|}
\hline \multirow[t]{2}{*}{ Fish species } & \multirow[t]{2}{*}{$n$} & Length $(\mathrm{cm})$ & $\begin{array}{l}\text { Total } \mathrm{Hg} \\
(\mathrm{mg} / \mathrm{kg}, \mathrm{ww})\end{array}$ & $\delta^{15} \mathrm{~N}(\% 0)$ & $\delta^{13} \mathrm{C}(\% 0)$ \\
\hline & & $\begin{array}{l}\text { Mean } \pm \text { SD } \\
\text { (Range) }\end{array}$ & $\begin{array}{l}\text { Mean } \pm \text { SD } \\
\text { (Range) }\end{array}$ & $\begin{array}{l}\text { Mean } \pm \text { SD } \\
\text { (Range) }\end{array}$ & $\begin{array}{l}\text { Mean } \pm \text { SD } \\
{[(\text { Range })]}\end{array}$ \\
\hline C. punctatus & 6 & $\begin{array}{l}15.03 \pm 0.74 \\
(14.20-16.20)\end{array}$ & $\begin{array}{l}144.53 \pm 31.29 \\
(108.19-200.95)\end{array}$ & $\begin{array}{l}11.29 \pm 1.18 \\
(9.85-12.79)\end{array}$ & $\begin{array}{l}-23.83 \pm 1.77 \\
{[-26.82-(-21.98)]}\end{array}$ \\
\hline M. vittatus & 3 & $\begin{array}{l}12.10 \pm 0.76 \\
(11.30-12.80)\end{array}$ & $\begin{array}{l}165.91 \pm 40.64 \\
(126.37-207.56)\end{array}$ & $\begin{array}{l}9.33 \pm 2.16 \\
(7.09-11.40)\end{array}$ & $\begin{array}{l}-23.59 \pm 3.14 \\
{[-26.76-(-20.49)]}\end{array}$ \\
\hline N. nandus & 20 & $\begin{array}{l}14.00 \pm 1.25 \\
(11.80-15.80)\end{array}$ & $\begin{array}{l}467.75 \pm 142.68 \\
(143.17-698.73)\end{array}$ & $\begin{array}{l}9.38 \pm 1.03 \\
(7.44-11.14)\end{array}$ & $\begin{array}{l}-23.02 \pm 2.70 \\
{[-27.47-(-16.30)]}\end{array}$ \\
\hline P. sophore & 17 & $\begin{array}{l}10.09 \pm 1.17 \\
(8.00-11.90)\end{array}$ & $\begin{array}{l}162.46 \pm 72.89 \\
(77.06-368.16)\end{array}$ & $\begin{array}{l}10.20 \pm 1.44 \\
(8.07-12.61)\end{array}$ & $\begin{array}{l}-23.86 \pm 1.89 \\
{[-25.27-(-17.46)]}\end{array}$ \\
\hline$X$. cancila & 7 & $\begin{array}{l}26.55 \pm 2.93 \\
(20.5-29.3)\end{array}$ & $\begin{array}{l}800.42 \pm 279.36 \\
(429.04-1263.54)\end{array}$ & $\begin{array}{l}10.71 \pm 0.70 \\
(9.83-11.77)\end{array}$ & $\begin{array}{l}-23.28 \pm 2.57 \\
{[-26.33-(-19.43)]}\end{array}$ \\
\hline
\end{tabular}


Table 2 Regression of mercury concentrations (log-THg) against length $(\mathrm{cm})$, and $\delta^{15} \mathrm{~N}$ were analyzed for individual fish species. Also included in the table are a regression of $\delta^{15} \mathrm{~N}$ and $\delta^{13} \mathrm{C}$ against the length of different species. The sample size $(n)$, intercept, slope, $R^{2}$ and $p$-values are given for each regression. Significant results for $p<0.05$ at $\alpha=0.05$ (95\% confidence interval) are written in bold.

\begin{tabular}{|c|c|c|c|c|c|c|c|}
\hline Species & Regression & (n) & Intercept & Slope & S.E. of Slope & $\boldsymbol{R}$ & $p$-value \\
\hline All & $\log$-THg vs. $\delta^{15} \mathrm{~N}$ & 53 & 2.60 & -0.02 & 0.03 & 0.07 & 0.64 \\
\hline \multirow[t]{4}{*}{ C. punctatus } & log-THg vs. Length & 6 & 1.89 & 0.02 & 0.06 & 0.15 & 0.78 \\
\hline & $\log -\mathrm{THg}$ vs. $\delta^{15 \mathrm{~N}}$ & 6 & 2.01 & 0.01 & 0.04 & 0.17 & 0.75 \\
\hline & $\delta^{15} \mathrm{~N}$ vs. Length & 6 & 15.14 & -0.26 & 0.78 & 0.16 & 0.76 \\
\hline & $\delta^{13} \mathrm{C}$ vs. Length & 6 & 5.03 & -1.92 & 0.71 & 0.81 & 0.05 \\
\hline \multirow[t]{4}{*}{ M. vittatus } & log-THg vs. Length & 3 & 0.49 & 0.14 & 0.01 & 0.99 & 0.06 \\
\hline & $\log -\mathrm{THg}$ vs. $\delta^{15 \mathrm{~N}}$ & 3 & 2.67 & -0.05 & 0.01 & 0.99 & 0.06 \\
\hline & $\delta^{15} \mathrm{~N}$ vs. Length & 3 & 43.41 & -2.82 & 0.51 & 0.98 & 0.16 \\
\hline & $\delta^{13} \mathrm{C}$ vs. Length & 3 & -42.52 & 1.57 & 3.85 & 0.38 & 0.75 \\
\hline \multirow[t]{4}{*}{ N. nandus } & log-THg vs. Length & 20 & 2.09 & 0.04 & 0.03 & 0.31 & 0.19 \\
\hline & $\log -\mathrm{THg}$ vs. $\delta^{15} \mathrm{~N}$ & 20 & 1.97 & 0.07 & 0.03 & 0.47 & 0.038 \\
\hline & $\delta^{15} \mathrm{~N}$ vs. Length & 20 & 8.58 & 0.06 & 0.19 & 0.07 & 0.77 \\
\hline & $\delta^{13} \mathrm{C}$ vs. Length & 20 & -44.71 & 1.55 & 0.36 & 0.72 & $<0.001$ \\
\hline \multirow[t]{4}{*}{ P. sophore } & log-THg vs. Length & 17 & 2.43 & -0.03 & 0.04 & 0.17 & 0.52 \\
\hline & $\log -\mathrm{THg}$ vs. $\delta^{15} \mathrm{~N}$ & 17 & 1.88 & 0.03 & 0.03 & 0.24 & 0.35 \\
\hline & $\delta^{15} \mathrm{~N}$ vs. Length & 17 & 9.36 & 0.08 & 0.32 & 0.07 & 0.79 \\
\hline & $\delta^{13} \mathrm{C}$ vs. Length & 17 & -24.18 & 0.03 & 0.42 & 0.02 & 0.94 \\
\hline \multirow[t]{4}{*}{$X$. cancila } & log-THg vs. Length & 7 & 3.28 & -0.02 & 0.02 & 0.27 & 0.55 \\
\hline & $\log -\mathrm{THg}$ vs. $\delta^{15 \mathrm{~N}}$ & 7 & 4.76 & -0.18 & 0.06 & 0.78 & 0.041 \\
\hline & $\delta^{15 \mathrm{~N}}$ vs. Length & 7 & 6.08 & 0.18 & 0.08 & 0.72 & 0.07 \\
\hline & $\delta^{13} \mathrm{C}$ vs. Length & 7 & -27.94 & 0.18 & 0.39 & 0.19 & 0.67 \\
\hline
\end{tabular}

No significant relationship of stable isotopes, $\delta^{15} \mathrm{~N}$ and $\delta^{13} \mathrm{C}$, with total fish length was found in the studied fish species except for $N$. nandus, which had a significantly positive relationship between $\delta^{13} \mathrm{C}$ and total length $(\mathrm{p}<$ $0.001, \mathrm{R}=0.72$; Table 2). Interestingly, $N$. nandus was the only species having a wide variation in $\delta^{13} \mathrm{C}$ values with both the lowest and highest values of carbon signatures (Table 1), indicating a correspondingly wide range of habitat use and carbon sources in the diet as was the case of $T$. zilli observed in Lake Ziway (Tadiso et al., 2011). However, all other species seemed to consume the diet from the same locality and thus the same basic carbon sources, regardless of their size. The overall results indicate that the habitat within the fish community is dominated by pelagic carbon sources (Fig. 2) as can be inferred from light (more negative) carbon signatures (Bootsma et al., 1996; Deribe et al., 2014; Hecky \& Hesslein, 1995), a similar condition like the one possibly resulting from the eutrophication (Gautam \& Bhattarai, 2008), which is described by Eagles-Smith et al. (2008) for the eutrophic Clear Lake.

The slope of the regression equation of $\log$-THg and $\delta^{15} \mathrm{~N}$ values (as a measure of trophic magnification slope) can be used for the quantitative measurement and comparative studies of biomagnification rates among aquatic systems (Borgå et al., 2012; Lavoie et al., 2013). However, there was no relationship between $\log -\mathrm{THg}$ and $\delta^{15} \mathrm{~N}$, indicating that the biomagnification of mercury along the food web of
Jagadishpur Reservoir was not clear (Table 2). Another study in the Nepalese lake (Lake Phewa) by Sharma et al. (2013) also observed low biomagnification of THg through the food chain. Furthermore, a similar finding was reported in a tropical lake with a lower rate of biomagnification of $\mathrm{Hg}$, as indicated by the slope of the regression equation (Desta et al., 2006).

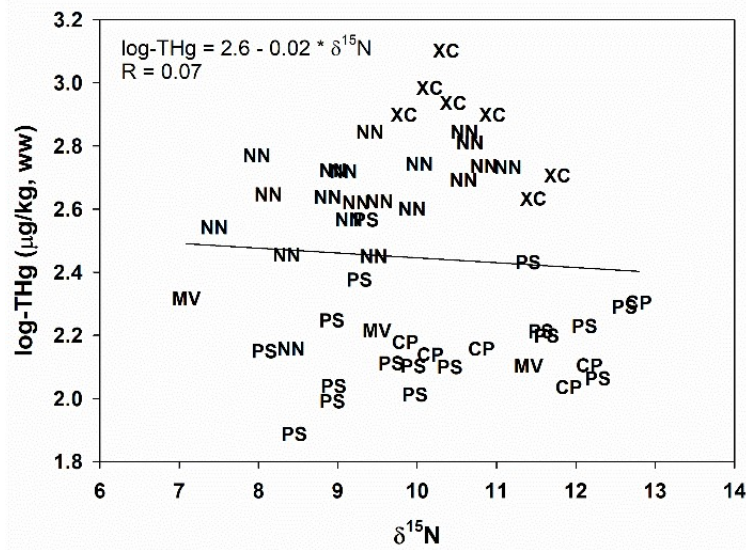

Figure 4 The regression between $\log -\mathrm{THg}(\mathrm{mg} / \mathrm{kg}$, ww) and $\delta^{15} \mathrm{~N}(\% 0)$ for all fish species from Jagadishpur Reservoir. Fish codes used in the figure are C. punctatus (CP), $M$. vittatus (MV), N. nandus (NN), P. sophore (PS), and $X$. 
cancila $(\mathrm{XC})$.

Lastly, the absence of representative fish species from the food chain in the studied lake might have some impacts hiding the relationship between $\mathrm{THg}$ and $\delta 15 \mathrm{~N}$ as described by Sharma et al. (2013).

\section{Conclusion}

The carnivorous fish had higher concentrations of $\mathrm{THg}$ compared to omnivorous and herbivorous fishes in Jagadishpur Reservoir; however, none of the fishes statistically exceeded WHO marketing guidelines. Mercury concentrations in the fish community of the Jagadishpur Reservoir did not show significant relationships with the length of fish and their trophic positions, except N. nandus. The fish community in the present study represented at least two trophic levels $\left(\Delta^{15} \mathrm{~N}>5.6\right)$; C. punctatus at the highest and $M$. vittatus the lowest based on $\delta^{15} \mathrm{~N}$ signatures, which was also supported by the stomach content analysis. There is a clear indication that the fish community in our samples revealed a low biomagnification rate of mercury, possibly due to no representation from all the trophic levels.

\section{Acknowledgements}

The financial support from the National Natural Science Foundation of China (Grant \# 41630754), Chinese Academy of Sciences (Grant \# XDB03030504, PIFI \# 2017VBC0003, 2020FYC0001), State Key Laboratory of Cryospheric Sciences (SKLCS-ZZ-2013-01-01), and University Grants Commission Nepal (CRG73/74-S\&T-04) are highly appreciated. Mr. Sudip Raj Niroula deserves our thanks for his help during the fieldwork.

\section{References}

Belger, L., \& Forsberg, B.R. (2006). Factors controlling Hg levels in two predatory fish species in the Negro river basin, Brazilian Amazon. Science of the Total Environment, 367, 451-459.

Bodaly, R.A., Rudd, J.W.M., Fudge, R.J.P., \& Kelly, C.A. (1993). Mercury concentrations in fish related to size of remote Canadian Shield lakes. Canadian Journal of Fisheries and Aquatic Sciences, 50, 980-987.

Bootsma, H.A., Hecky, R.E., Hesslein, R.H., \& Turner, G.F. (1996). Food partitioning among Lake Malawi nearshore fishes as revealed by stable isotope analysis. Ecology, 77, 1286-1290.

Borgå, K., Kidd, K., Muir, D., Berglund, O., Conder, J., Gobas, F.A., Kucklick, J., Malm, O., \& Powell, D.E. (2012). Trophic magnification factors: considerations of ecology, ecosystems, and study design. Integrated Environmental Assessment and Management, 8, 64-84.

Campbell, L.M., Hecky, R.E., Nyaundi, J., Muggide, R., \& Dixon, D.G. (2003). Distribution and food-web transfer of mercury in Napoleon and Winam Gulfs, Lake Victoria, East Africa. Journal of Great Lakes Research, 29, 267-282.

Campbell, L., Hecky, R.E., Dixon, D.G., \& Chapman, L.J. (2006). Food web structure and mercury transfer in two contrasting Ugandan highland crater lakes (East Africa). African Journal of Ecology, 44, 337-346.
Deribe, E., Masresha, A.E., Gade, P.A., Berger, S., Rosseland, B.O., Borgstrøm, R., Dadebo, E., Gebremariam, Z., Eklo, O.M., Skipperud, L., \& Salbu, B. (2014). Bioaccumulation of mercury in fish species from the Ethiopian Rift Valley Lakes. International Journal of Environmental Protection, 4, 15-22.

Desta, Z., Borgstrøm, R., Rosseland, B.O., \& Gebremariam, Z. (2006). Major differences in mercury concentrations of the African big barb, Barbus intermedius (R.) due to shifts in trophic position. Ecology of Freshwater Fish, 15, 532-543.

Desta, Z., Borgstrøm, R., Rosseland, B.O., \& Dadebo, E. (2007). Lower than expected mercury concentration in piscivorous African sharptooth catfish Clarias gariepinus (Burchell). Science of the Total Environment, 376, 134-142.

Donald, D.B., Wisel, B., \& Mohamed Anas, M.U. (2015). Species-specific mercury bioaccumulation in a diverse fish community. Environmental Toxicology and Chemistry, 134, 2846-2855.

Eagles-Smith, C.A., Suchanek, T.H., Colwell, A.E., \& Anderson, N.L. (2008). Mercury trophic transfer in a eutrophic lake: the importance of habitat-specific foraging. Ecological Applications, 18, A196-A212.

Freije, A., \& Awadh, M. (2009). Total and methylmercury intake associated with fish consumption in Bahrain. Water and Environment Journal, 23, 155-164.

Garcia, E., \& Carignan, R. (2000). Mercury concentrations in northern pike (Esox lucius) from boreal lakes with logged, burned, or undisturbed catchments. Canadian Journal of Fisheries and Aquatic Sciences, 57(Suppl.2), 129135.

Gautam, B., \& Bhattarai, B. (2008). Seasonal changes in water quality parameters and sediment nutrients in Jagadishpur Reservoir, a Ramsar Site in Nepal. Nepal Journal of Science and Technology, 9, 149-156.

Hecky, R.E., \& Hesslein, R.H. (1995). Contributions of benthic algae to lake food webs as revealed by stable isotope analysis. Journal of North American Benthological Society, 14, 631-653.

IUCN. (2015). Wetlands for the future: Biodiversity and livelihoods assessment in Jagadishpur Reservoir Ramsar Site. International Union for Conservation of Nature, Nepal.

Lavoie, R.A., Jardine, T.D., Chumchal, M.M., Kidd, K.A., \& Campbell, L.M. (2013). Biomagnification of mercury in aquatic food webs: a worldwide meta-analysis. Environmental Science \& Technology, 47, 13385-13394.

Lockhart, W.L., Stern, G.A., Low, G., Hendzel, M., Boila, G., Roach, P., Evans, M.S., Billeck, B.N., DeLaronde, J., Friesen, S., Kidd, K., Atkins, S., Muir, D.C.G., Stoddart, M., Stephens, G., Stephenson, S., Harbicht, S., Snowshoe, N., Grey, B., Thompson, S., \& DeGraff, N. (2005). A history of total mercury in edible muscle of fish from lakes in northern Canada. Science of the Total Environment, 351-352, 427-463.

Pandey, A., Sharma, C.M., Kang, S., Zhang, Q., Tripathee, L., Guo, J., Li, X., Sun, S., Paudyal, R., Acharya, P., \& Sillapää, M. (2017). Mercury concentrations in the fish community from Indrawati River, Nepal. Bulletin of Environmental Contamination and Toxicology, 99, 500-505.

Post, D.M. (2002). Using stable isotopes to estimate trophic position: models, methods and assumptions. Ecology, 83, 
703-718.

Sharma, C.M., Basnet, S., Kang, S., Rosseland, B.O., Zhang, Q., Pan, K., Borgstrøm, R., Li, Q., Wang, W.X., Huang, J., Teien, H.C., \& Sharma, S. (2013). Mercury concentrations in commercial fish species of Lake Phewa, Nepal. Bulletin of Environmental Contamination and Toxicology, 91, 272-277.

Sharma, C.M., Borgstrøm, R., Huitfeldt, J.S., \& Rosseland, B.O. (2008). Selective exploitation of large pike Esox lucius-Effects on mercury concentrations in fish populations. Science of the Total Environment, 399, 33-40.

Sharma, C.M., Rosseland, B.O., Almvik, M., \& Eklo, O.M. (2009). Bioaccumulation of organochlorine pollutants in the fish community in Lake Årungen, Norway. Environmental Pollution, 157, 2452-2458.

Shoeb, M., Hossain, M.A., Kibria, M.G., Mustafa. T., \& Nahar, N. (2017). Bioaccumulation of mercury in fish species from different trophic level. Journal of Food Science and Engineering, 7, 363-367.

Swain, E.B., Jakus, P.M., Rice, G., Lupi, F., Maxson, P.A., Pacyna, J.M., Penn, A., Spiejel, S.J., \& Veiga, M.M. (2007). Socioeconomic consequences of mercury use and pollution. Ambio, 36, 45-61.

Tadiso, T.M., Borgstrøm, R., \& Rosseland, B.O. (2011). Mercury concentrations are low in commercial fish species of Lake Ziway, Ethiopia, but stable isotope data indicated biomagnification. Ecotoxicology and Environmental Safety, 74, 953-959.

Taylor, D.L., Kutil, N.J., Malek, A.J., \& Collie, J.S. (2014). Mercury bioaccumulation in cartilaginous fishes from Southern New England coastal waters: Contamination from a trophic ecology and human health perspective. Marine Environmental Research, 99, 20-33.
Thapa, D.S., Sharma, C.M., Kang, S., \& Sillapää, M. (2014). The risk of mercury exposure to the people consuming fish from Lake Phewa, Nepal. Internatiopnal Journal of Environmental Research and Public Health, 11, 6771-6779.

Vander Zanden, M.J., \& Rasmussen, J.B. (2001). Variation in $\delta^{15} \mathrm{~N}$ and delta $\delta^{13} \mathrm{C}$ trophic fractionation: implications for aquatic food web studies. Limnology and Oceanography, 46, 2061-2066.

Wang, Y., Xie, Q., Xu, Q., Xue, J., Zhang, C., \& Wang, D. (2019). Mercury bioaccumulation in fish in an artificial lake used to carry out cage culture. Journal of Environmental Sciences, 78, 352-359.

Watras, C.J., Back, R.C., Halvorsen, S., Hudson, R.J.M., Morrison, K.A., \& Wente, S.P. (1998). Bioaccumulation of mercury in pelagic freshwater food webs. Science of the Total Environment, 219, 183-208.

WHO. (2008). Guidance for identifying populations at risk from mercury exposure. UNEP DTIE Chemical Branch and WHO Department of Food Safety, Zoonoses and Foodborne Deseases, Geneva, Switzerland.

Willacker, J., Eagles-Smith, C.A., Lutz, M.A., Tate, M.T., Lepak, J.M., \& Ackerman, J.T. (2016). Reservoirs and water management influence fish mercury concentrations in the western United States and Canada. Science of the Total Environment, 568, 739-748.

Xu, Q., Zhao, L., Wang, Y., Xie, Q., Yin, D., Feng, X., \& Wang, D. (2018). Bioaccumulation charateristics of mercury in fish in the Three Gorges Reservoir, China. Environmental Pollution, 243, 115-126. 